\title{
Oxidative stress and liver damage in birds exposed to diclofenac and lead
}

\author{
Jitka Osičková1, Hana Band’ouchová1, Veronika Kováčová1, Jiří Král ${ }^{1}$, Ladislav Novotný², \\ Karel Ondráček ${ }^{1}$, Miroslav Pohanka ${ }^{3}$, Jana Sedláčková1, Hana Škochová1, \\ František Vitula ${ }^{1}$, Jiř́i Pikula ${ }^{1}$
}

\begin{abstract}
${ }^{1}$ University of Veterinary and Pharmaceutical Sciences Brno, Faculty of Veterinary Hygiene and Ecology, Department of Ecology and Diseases of Game, Fish and Bees, ${ }^{2}$ Faculty of Veterinary Medicine,

Department of Pathological Morphology and Parasitology, Brno, Czech Republic

${ }^{3}$ University of Defence, Faculty of Military Health Sciences, Hradec Králové,

Czech Republic
\end{abstract}

Received May 12, 2014

Accepted September 17, 2014

\begin{abstract}
Responses of wildlife to multiple stressors fit in the ecological concept of trade-off. While toxicity of non-steroidal anti-inflammatory drugs and heavy metals for free-ranging birds has been shown in single exposures, the present study aims to evaluate oxidative stress, and liver and kidney damage caused by single and combined effects of diclofenac and lead in the Japanese quail. Forty Japanese quail (Coturnix coturnix japonica) were divided into equal groups of controls, diclofenac, $\mathrm{Pb}$, and $\mathrm{Pb}+$ diclofenac exposures. The birds were exposed to the respective chemicals through insertion of lead shots $(1.5 \mathrm{~g})$ into the crop on day 0 of the experiment and/ or administration of $5 \mathrm{mg} / \mathrm{kg}$ of diclofenac intramuscularly in two treatments on days 0 and 5 . Groups in liver and kidney tissues of birds were then compared after 10 days using histopathology and biochemistry markers such as glutathione reductase (GR), ferric reducing antioxidant power (FRAP), and lipid peroxidation measured as total thiobarbituric acid reactive species (TBARS). The liver damage score gradient was $\mathrm{Pb}+$ diclofenac exposure group $>\mathrm{Pb}$ exposure group $>$ diclofenac exposure group and hepatic TBARS values were significantly increased in the group of birds exposed to a combination of diclofenac and lead compared to the healthy control group. The study has shown that, apart from the reported nephrotoxicity of diclofenac, hepatic toxicity should also be considered. Avian clinicians should be cautious when selecting drugs for therapy of wild birds with unknown history of exposure to toxic substances.
\end{abstract}

Total antioxidant capacity, lipid peroxidation, non-steroidal anti-inflammatory drugs, heavy metals, Japanese quail

Exposure of birds to multiple stressors elicits physiological costs and trade-off responses that may be represented by oxidative stress as a non-specific biochemical process (Constantini and Møller 2009). While sub-lethal adverse effects are underreported in ecotoxicology (Pikula et al. 2010), various interactions, e.g. synergistic effects between natural stressors and environmental pollutants, are common (Fry 1995; Holmstrup et al. 2010).

Veterinary medicines used in significant quantities for the therapy and control of animal diseases, such as non-steroidal anti-inflammatory drugs, may enter the environment and pose serious threats to wildlife. Diclofenac is extremely toxic for free-living birds, primarily for Gyps vulture species in which it has caused population declines (Oaks et al. 2004; S chultz et al. 2004; Meteyer et al. 2005; Das et al. 2011). Vultures are exposed to diclofenac through feeding on carcasses of livestock that were treated with this drug before death (Green et al. 2006). Findings in affected birds include residues of diclofenac, visceral gout and renal failure (Oaks et al. 2004).

Both wild and captive birds are at risk of lead toxicosis (Samour and Naldo 2002; 
Finkelstein et al. 2012; Pikula et al. 2013). Poisonings of aquatic birds after ingestion of lead shots have been well documented globally (Fischer et al. 2006). However, despite high conservation concern this issue in terrestrial species such as raptors and upland game birds remains largely to be addressed (Fischer et al. 2006). Importantly, species such as California condors were brought to the brink of extinction because of lead poisoning (Finkelstein et al. 2012). Apart from ammunition as a source of lead, soil contamination by lead-based paint has been reported to be responsible for poisoning of vultures in captivity (Pikula et al. 2013). While lead impairs many physiological functions in birds including general health, growth, blood, immune, and reproductive systems (Fair and Ricklefs 2002), the liver is important for the metabolism and excretion of lead in bile.

Oxidative stress results from an imbalance between antioxidant defence and production of reactive oxygen or nitrogen species. Formation of radicals causes oxidative damage to biomolecules such as lipids, proteins, and DNA, and may overcome the organism's defence (Halliwell and Gutteridge 2007). Free metal ions can cause oxidative stress by increasing the formation of reactive oxygen species in birds (Koivula and Eeva 2010). Oxidative stress has a critical role in the pathophysiology of tissue damage. Similarly, diclofenac has been shown to induce oxidative damage in liver (Islas-Flores et al. 2013).

Toxicity of non-steroidal anti-inflammatory drugs and heavy metals for free-ranging birds has been shown in single exposures. Considering the major metabolic role of liver in birds (Vitula et al. 2011) and kidneys as a target organ for adverse effects of both lead and diclofenac (Oaks et al. 2004; Meteyer et al. 2005), the present study aimed to evaluate oxidative stress, and liver and kidney damage caused by single and combined effects of diclofenac and lead in Japanese quail. Our intention was to complement field observations with results from laboratory experiments. Therefore, we performed evidence-based avian toxicity tests using the Japanese quail as a standard experimental avian species (Romijn et al. 1995).

\section{Materials and Methods}

The experiment was conducted with the approval of the institutional Ethics Committee of the University of Veterinary and Pharmaceutical Sciences Brno, Czech Republic. The Japanase quail was used as a model bird species in accordance with standard methods OECD 205 (Guideline for the testing of chemicals-Avian dietary Toxicity Test, 1984). The design of the experiment has been described previously (Osickova et al. 2012). Briefly, two-month-old Japanese quail males (Coturnix coturnix japonica) were used as a model indicator of avian toxicity (Romijn et al. 1995). A total of 40, 2-month-old male birds with the mean weight of $180 \mathrm{~g}$ were randomly placed in 4 groups ( 1 control and 3 experimental groups - diclofenac, $\mathrm{Pb}$, and $\mathrm{Pb}+$ diclofenac exposure; 10 birds per group). Birds exposed to lead received six ammunition lead shots at a total dose of $1.5 \mathrm{~g}$ into the gastrointestinal tract by crop insertion on day 0 of the experiment (Sellier \& Bellot, Vlašim, Czech Republic); and a total dose of $5 \mathrm{mg} / \mathrm{kg}$ of diclofenac (Dolmina inj. sol. $5 \times 3 \mathrm{ml} / 75 \mathrm{mg}$, Zentiva, Czech Republic) was divided into treatments on days 0 and 5, and administered intramuscularly. Combined exposure groups received equal doses of both lead and diclofenac as single exposure groups $(1.5 \mathrm{~g}$ of lead shots $+2 \times 2.5 \mathrm{mg} / \mathrm{kg}$ of diclofenac). The quail were provided with standard feed mixture and water ad libitum. Responses to the single and combined toxic loads were examined after 10 days of exposure when samples of liver and kidney tissues were collected for histopathology and biochemistry from birds euthanised by decapitation. The liver and kidney tissues were either conserved in $10 \%$ buffered formalin and later processed using routine histological technique to obtain $5 \mu \mathrm{m}$ sections stained with haematoxylin and eosin or stored deep frozen at $-80^{\circ} \mathrm{C}$ until biochemical analyses.

A five-grade semi-quantitative system for histopathological liver damage scoring was used to compare birds from single and combined exposure groups to controls with the definition of scores as follows: $0=$ normal microscopic structure; 1 = mild damage, sporadic hepatocytes with vacuolar dystrophy, mild perivascular infiltrates in portal fields; 2 = moderate damage, focal vacuolar dystrophy of hepatocytes, moderate grades of perivascular infiltrates in portal fields; 3 = severe damage, marked diffuse vacuolar dystrophy of hepatocytes, sporadic necroses of hepatocytes, extensive inflammatory perivascular infiltrates; 4 = severe diffuse damage, focal necroses of hepatocytes with infiltration by heterophils, extensive inflammatory perivascular infiltrates; $5=$ massive necroses of hepatocytes (Kral et al. 2012). Biochemistry indicators such as glutathione reductase, lipid peroxidation and total antioxidant capacity were measured in tissue samples as described previously (Benzie and Strain 1996; Paskova et al. 2008; Pohanka et al. 2011). Activity of glutathione reductase (GR) was determined from the rate of NADPH oxidation. The level of lipid peroxidation in avian tissues was evaluated as total thiobarbituric acid reactive species (TBARS). The total antioxidant 
capacity was measured using the ferric reducing antioxidant power assay (FRAP). Analyses of $\mathrm{Pb}$ and diclofenac in bird tissues were not performed in the present study.

The data analysis software Statistica for Windows ${ }^{\circledR} 10$ (StatSoft, Inc., Tulsa, OK, USA) was used to compare different groups using procedures such as one-way analysis of variance (ANOVA), post-hoc analysis of means by the LSD test, Levene's method to test for the homogeneity of variances, log-transformation of non-homogenous parameters prior to analysis and comparison with the non-parametric Kruskal-Wallis test, median and chi-square tests. Levels of statistical significance of differences of $P<0.05$ and $P<0.01$ were considered.

\section{Results}

While there were no histopathological findings in the liver of control birds, liver damage scores in Japanese quail exposed either to single or combined effects of diclofenac and lead were significantly higher (Fig. 1). The damage score gradient was $\mathrm{Pb}+$ diclofenac-exposure group $>\mathrm{Pb}$-exposure group $>$ diclofenac-exposure group. Morphological changes in the liver were represented by vacuolar dystrophy and varied from moderate to severe grades in the combined exposure group. The size of vacuoles and severity of damage were most pronounced in the pericentral hepatocytes. Kidneys of both controls and exposure groups were without any histopathological changes.

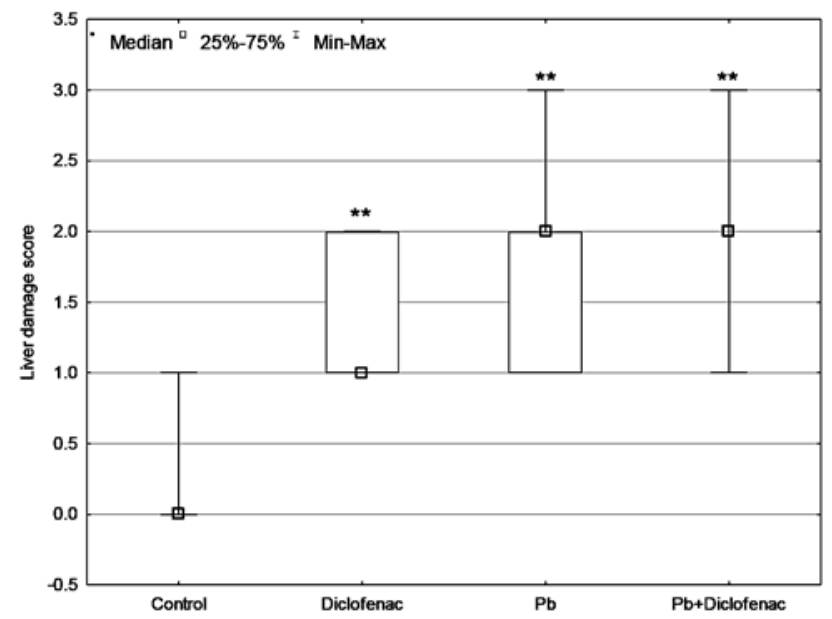

Fig. 1. Histopathological liver damage score in control Japanese quails and birds exposed to single and combined doses of diclofenac and lead $(\mathrm{Pb})$.

$\mathrm{N}=10$ randomly selected males in each group, ${ }^{* *}=P<0.01$ compared to the control group.

Hepatic values of lipid peroxidation measured as total thiobarbituric acid reactive species (TBARS) were significantly increased in the group of birds exposed to a combination of diclofenac and lead when compared to the healthy control group as well as diclofenac only (Fig. 2). All other differences of TBARS, activity of glutathione reductase (GR), and ferric reducing antioxidant power assay (FRAP) in the liver and kidneys were non-significant.

\section{Discussion}

The present experimental study examined the hypothesis that a sub-lethal combination of diclofenac (i.e., a non-steroidal anti-inflammatory drug) and lead induces more pronounced effects in birds than single exposures (Osickova et al. 2012). The doses were chosen based on the fact that approximately $25 \%$ of lead $(2.5 \mathrm{mg} / \mathrm{kg} \times 2)$ weight are absorbed 


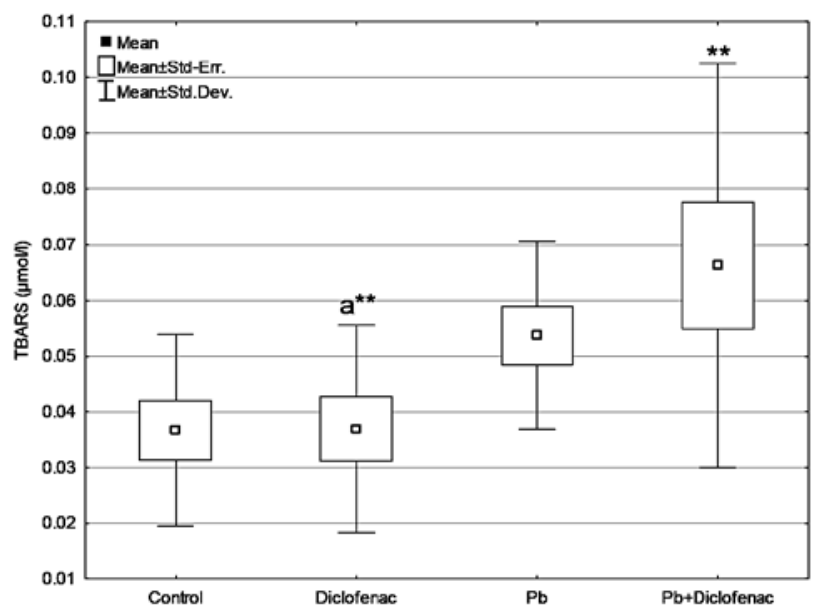

Fig. 2. Lipid peroxidation measured as total thiobarbituric acid reactive species (TBARS) values in the liver of control quail, and quail exposed to single and combined doses of diclofenac and lead $(\mathrm{Pb})$.

$\mathrm{N}=10$ randomly selected males in each group, $* *=P<0.01$ compared to the control group, a**=P<0.01 represents significant difference between diclofenac and $\mathrm{Pb}+$ diclofenac exposure groups

from the digestive tract within 10 days of administration and are known to exert sublethal effects (Pikula et al. 2010). Likewise, the above-mentioned dose of diclofenac results in sublethal effects according to Hussain et al. (2008). It is absorbed quickly both following oral and intramuscular injection; the latter mode of administration was selected to ensure application of equal doses and uniform pharmacological effects in each experimental bird (Graham et al. 2005). Our hypothesis was confirmed by measurement of an oxidative stress biomarker.

Importantly, histopathology proved to be a more sensitive method to detect liver tissue damage than biochemical measurement of lipid peroxidation. As shown by comparison of Figs 1 and 2, liver damage scores differed significantly from controls both in single and combined exposures, with a significant increase only in the combined exposure when evaluated by biochemistry. Hepatocellular cytoplasmic vacuoles represent early dystrophic changes that are reversible when the cause is removed; they are non-specific and may develop due to exposure of birds to many different toxins (Pikula et al. 2010; Skocovska et al. 2007).

Unexpectedly, histopathology revealed normal kidneys in all exposed groups of birds. Likewise, biochemical indicators associated with oxidative stress were not altered in kidneys of birds in this experiment. These findings contrast with reported toxicity of diclofenac in scavenger birds and adverse effects observed in kidneys of vultures (O a ks et al. 2004; Meteyer et al. 2005; Green et al. 2006; Das et al. 2011; Saini et al. 2012) as well as with the increased production of reactive oxygen species (ROS) observed in avian cell cultures in vitro (Naidoo and Swan 2009). Adverse effects of diclofenac in kidney tissue may differ in various species of birds (Meteyer et al. 2005). The severity of action is dose-dependent. Higher doses are required to produce toxicity but, surprisingly, visceral gout was not observed following a dose as high as $20 \mathrm{mg}$ of diclofenac per $1 \mathrm{~kg}$ of body weight in the Japanese quail (Hussain et al. 2008). Vultures, on the other hand, are highly sensitive, and a dose of $0.8 \mathrm{mg} / \mathrm{kg}$ produced marked effects and mortality in Gyps fulvus and Gyps africanus; and the LD50 amounted to $0.1-0.2 \mathrm{mg} / \mathrm{kg}$ in Gyps bengalensis (Swan 
et al. 2006). Susceptibility of vultures to diclofenac causing renal tubular damage results from a combination of increased production of reactive oxygen species, interference with uric acid transport, and the duration of exposure (Naid oo and Swan 2009).

The results of this study document the fact that the liver is a major detoxifying organ and the main source of ROS generation in birds (Paskova et al. 2011; Vitula et al. 2011). Therefore, it is the first organ to show damage. Low doses of both toxicants and the short duration of sub-lethal exposure were probably within its detoxifying threshold. Differences in avian responses to toxic exposure may also be influenced by species-specific and tissuespecific susceptibility (Meteyer et al. 2005; Hussain et al. 2008; Vitula et al. 2011).

It has previously been shown that experiments to examine combination toxicity of multiple stressors can provide environmentally relevant data and a better insight into real toxicological problems in wildlife (Bandouchova et al. 2011; Pikula et al. 2010). Our findings indicate that, apart from the reported nephrotoxicity of diclofenac, hepatic toxicity should also be considered. Regarding clinical avian medicine, one should be very cautious when selecting pharmaceuticals for the treatment of wild birds with unknown history of exposure to toxic substances.

\section{Acknowledgements}

This study was supported by the Internal Grant Agency of the University of Veterinary and Pharmaceutical Sciences Brno (Project No. 29/2013/FVHE).

\section{References}

Bandouchova H, Pohanka M, Vlckova K, Damkova V, Peckova L, Sedlackova J, Treml F, Vitula F, Pikula J 2011: Biochemical responses and oxidative stress in Francisella tularensis infection: a European brown hare model. Acta Vet Scand 53: 2

Benzie IFF, Strain JJ 1996: The ferric reducing ability of plasma (FRAP) as a measure of "antioxidant power": The FRAP Assay. Anal Biochem 239: 70-76

Constantini D, Møller AP 2009: Does immune response cause oxidative stress in birds? A meta-analysis. Comp Biochem Physiol 153: 339-344

Das D, Cuthbert JR, Jakati DR, Prakash V 2011: Diclofenac is toxic to the Himalayan Vulture Gyps himalayensis. Bird Conserv Int 21: 72-75

Fair JM, Ricklefs RE 2002: Physiological, growth and immune responses of Japanese quail chicks to the multiple stressors of immunological challenge and lead shot. Arch Environ Contam Toxicol 42: 77-87

Finkelstein ME, Doak DF, George D, Burnett J, Brandt J, Church M, Grantham J, Smith DR 2012: Lead poisoning and the deceptive recovery of the critically endangered California condor. Proc Natl Acad Sci USA 109: 1144911454

Fisher IJ, Pain DJ, Thomas VG 2006: A review of lead poisoning from ammunition sources in terrestrial birds. Biol Conserv 131: 421-432

Fry MD 1995: Reproductive effects in birds exposed to pesticides and industrial chemicals. Environ Health Perspect 103: 165-171

Graham JE, Kollias-Baker C, CraigmillL AL, Thomasy SM, Tell LA 2005: Pharmacokinetics of ketoprofen in Japanese quail (Coturnix japonica). J Vet Pharmacol Ther 28: 399-402

Green RE, Taggart MA, Das D, Pain DJ, Kumar CS, Cunningham AA, Cuthbert R 2006: Collapse of Asian vulture populations: risk of mortality from residues of the veterinary drug diclofenac in carcasses of treated cattle. J Appl Ecol 43: 949-956

Halliwell B, Gutteridge J 2007: Free radicals in biology and medicine. Oxford University Press, 888 p.

Holmstrup M, Bindesbøl AM, Oostingh GJ, Duschl A, Scheil V, Köhler HR, Loureiro S, Soares AMVM, Ferreira ALG, Kienle C, Gerhardt A, Laskowski R, Kramarz PE, Bayley M, Svendsen C, Spurgeon DJ 2010: Interactions between effects of environmental chemicals and natural stressors: A review. Sci Total Environ 408: $3746-3762$

Hussain I, Khan MZ, Khan A, Javed I, Saleemi MK 2008: Toxicological effects of diclofenac in four avian species. Avian Pathol 37: 315-321

IIslas-Flores H, Gómez-Oliván LM, Galar-Martínez M, Colín-Cruz A, Neri-Cruz N, García-Medina S 2013: Diclofenac-induced oxidative stress in brain, liver, gill and blood of common carp (Cyprinus carpio). Ecotoxicol Environ Saf 92: 32-38

Koivula MJ, Eeva T 2010: Metal-related oxidative stress in birds. Environ Pollut 158: 2359-2370

Kral J, Pikula J, Bandouchova H, Damkova V, Hilscherova K, Misik J, Novotny L, Ondracek K, Osickova J, Mlcakova V, Pohanka M, Skochova H, Vitula F, Treml F 2012: Avian high-dose toxicity of cyanobacterial biomass. Neuroendocrionol Lett 33: 161-165 
Meteyer CU, Rideout BA, Gilbert M, Shivaprasad HL, Oaks JL 2005: Pathology and proposed pathophysiology of diclofenac poisoning in free-living and experimentally exposed oriental white-backed vultures (Gyps bengalensis). J Wild Dis 41: 707-716

Naidoo V, Swan GE 2009: Diclofenac toxicity in Gyps vultures is associated with decreased uric acid excretion and not renal portal vasoconstriction. Comp Biochem Physiol C Toxicol Pharmacol 149: 269-274

Oaks JL, Gilbert M, Virani MZ, Watson RT, Meteyer CU, Rideout BA, Shivaprasad HL, Ahmed S, Chaudhry MJI, Arshad M, Mahmood S, AlI A, Khan AA 2004: Diclofenac residues as the cause of vulture population decline in Pakistan. Nature 427: 630-633

Osickova J, Skochova H, Ondracek K, Kral J, Damkova V, Peckova L, Pohanka M, Vitula F, Bandouchova H, Pikula J 2012: Risk of single and combined exposure of birds to non-steroidal anti-inflammatory drugs and lead. Neuroendocrinol Lett 33: 145-150

Paskova V, Adamovsky O, Pikula J, Skocovska B, Bandouchova H, Horakova J, Babica P, Marsalek B, Hilscherova K 2008: Detoxification and oxidative stress responses along with microcystins accumulation in Japanese quail exposed to cyanobacterial biomass. Sci Total Environ 398: $34-47$

Paskova V, Paskerova H, Pikula J, Bandouchova H, Sedlackova J, Hilscherova K 2011: Combined exposure of Japanese quails to cyanotoxins, Newcastle virus and lead: Oxidative stress responses. Ecotoxicol Environ Saf 74: $2082-2090$

Pikula J, Bandouchova H, Hilscherova K, Paskova V, Sedlackova J, Adamovsky O, Knotkova Z, Lany P, Machat J, Marsalek B, Novotny L, Pohanka M, Vitula F 2010: Combined exposure to cyanobacterial biomass, lead and the Newcastle virus enhances avian toxicity. Sci Total Environ 408: 4984-4992

Pikula J, Hajkova P, Bandouchova H, Bednarova I, Adam V, Beklova M, Kral J, Ondracek K, Osickova J, Pohanka M, Sedlackova J, Skochova, H, Sobotka, Treml F, Kizek R 2013: Lead toxicosis of captive vultures: case description and responses to chelation therapy. BMC Vet Res 9: 11

Pohanka M, Bandouchova H, Vlckova K, Karasova Zdarova J, Kuca K, Damkova V, Peckova L, Vitula F, Pikula J 2011: Square wave voltammetry on screen printed electrodes: comparison to ferric reducing antioxidant power in plasma from model laboratory animal (Grey partridge) and comparison to standard antioxidants. J Appl Biomed 9: 103-109

Romijn CA, Grau R, Guth JA, Harrison EG, Jackson CM, Lefebvre B, Smith WW, Street JR 1995: The use of Japanese and bobwhite quail as indicator species in avian toxicity test. ECPA/GIFAP Environmental Round Table. Chemosphere 30: 1033-1040

Saini M, Taggart MA, Knopp D, Upreti S, Swarup D, Das A, Gupta P, Niessner R, Prakash V, Mateo R, Cuthbert $R$ 2012: Detecting diclofenac in livestock carcasses in India with an ELISA: A tool to prevent widespread vulture poisoning. Environ Pollut 160: 11-16

Samour JH, Naldo J 2002: Diagnosis and therapeutic management of lead toxicosis in falcons in Saudi Arabia. J Avian Med Surg 16: 16-20

Schultz S, Baral SH, Charman S, Cunningham AA, Das D, Ghalasigr, Goudarms, Green RE, Jones A, Nighot P, Pain DJ, Prakash V 2004: Diclofenac poisoning is widespread in declining vulture populations across the Indian subcontinent. Proc R Soc Lond B 271(Suppl): 458-460

Skocovska B, Hilscherova K, Babica P, Adamovsky O, Bandouchova H, Horakova J, Knotkova Z, Marsalek B, Paskova V, Pikula J 2007: Effects of cyanobacterial biomass on the Japanese quail. Toxicon 49: 793-803

Swan GE, Cuthbert R, Quevedo M, Green RE, Pain DJ, Bartels P, Cunningham AA, Duncan N, Meharg AA, Oaks JL, Parry-Jones J, Shultz S, Taggart MA, Verdoorn G, Wolter K 2006: Toxicity of diclofenac to gyps vultures. Biol Lett 2: 279-282

Vitula F, Peckova L, Bandouchova H, Pohanka M, Novotny L, Jira D, Kral J, Ondracek K, Osickova J, Zendulkova D, Rosenbergrova K, Treml F, Pikula J 2011: Mycoplasma gallisepticum infection in the grey partridge Perdix perdix: outbreak description, histopathology, biochemistry and antioxidant parameters. BMC Vet Res 7: 34 